\title{
CORPORATE SOCIAL RESPONSIBILITY (CSR)- AN INITIATIVE BY CORPORATE
} WORLD

KEYWORDS : Sustainability, Environmental, Social, Recycle, Responsibility, Enhance

\begin{abstract}
V.
\section{INTRODUCTION}

Corporate Social Reporting does not have any precise or fixed definitions. Some description focused on corporate compliance with following the applicable laws and few strongly believe that Social Responsibility is minimizing the environmental impacts are essential to long term growth and returns to shareholders. Corporate social Responsibility was initiated by big corporate organization by adding corporate social responsibility Reports or Sustainability Reports in Early 1990's. There was no such law or regulation in this regard at that time and no till time in most of the countries. The corporate imperative has gone from desirable to expect to require. India is the First Country which makes compulsory CSR for big Giant Corporate. The philosophy is that Corporations have a social and environmental impact in addition to their economic impact and these can enhance or diminish the collective good or wider societal progress. These new accountabilities are being demanded by civil societal groups with business leaders often responding to rather than leading the debate. CSR Reporting or Sustainability Reporting is a process whereby an organization publically discloses information about its interactions with and impact on the various societies and environments in which it operates. There are basically three pillars of sustainability Reporting: 1. Environmental Sustainability 2. Social Sustainability 3. Economic Sustainability.
\end{abstract}

\section{Environmental Sustainability:}

Environmental sustainability involves making responsible decisions and taking actions that are in the interest of protecting the natural world, with particular emphasis on preserving the capability of the environment to support human life. The arguments in favour of Environmental Sustainability are one that business survives only when human survive and humans will survive if the environment survive.

Humans live in natural environment and it is our responsibility to provide a livable environment to our next generations. The intergenerational argument contends that not being sustainable is an unfair burden to place on future generations, who ultimately will have to live with the consequences of our current behavior.

The naturalistic argument claims that nature has an intrinsic value and deserves preservation for its own sake. There are various cases in the world which indicates the importance of environmental sustainability, few are as follows: first case happened in India in 1984 at Bhopal, over 500,000 people were exposed to highly toxic chemicals that leaked from a union carbide India ltd. Plant, an expected 22000 people died and further generations also suffered from this disaster. Second case Happened in Gulf of Mexico, in 2010 and Famously known as Deepwater Horizon, an explosion and sinking of a BP deep water oil rig resulted in oil flowing for 87 days before the well was capped, discharging an estimated 4.9 million barrels of oil into the ocean with extensive damage to wildlife, marine ecology, coastlines and tourism across a huge area. One more disaster happened in 1986 at Chambly in Ukraine when a nuclear power plant accident killed over 4000 people, caused $3,50,000$ people to be permanently resettled and is still associated with environmental contamination, illness, deformities and cancers. These incidents have received a considerable response from the society, leaders and government. Environmental sustainability includes Climate Change including Global Warming, Waste during Production Which can't be recycled, Pollution and biodiversity.

\section{Social Sustainability:}

An organization is socially sustainable when its activities not only meet the needs of its current stakeholders but also support the ability of future generations to maintain healthy communities. Social sustainability activities of an organization include maintaining mutually beneficial relationships with employees, customers, the supply chain and community. The social sustainability is mostly considered as the Government Responsibility and least importance in the corporate world. Prominent example is collapse of Rana Place Building in Bangladesh where 1138 were died. most of the people in that building were very poorly paid garment workers who were working in unsafe conditions for long hours. It is the corporate's responsibility to minimize social discriminations in society.

\section{Further Social Sustainability includes Following:}

1. Child Labour:

The child labour deprives children of their child hood, their potential and their dignity. The child labour is banned in the mostly countries of the world including India but after that 215 million children are doing child labour.

\section{Ethical Trading:}

Corporate should do ethical trading and avoid unethical Trading which includes corruptions, bribery, predatory pricing, unethical marketing along with unfair use of the powers.

3. Supply Chain Management:

Multinationals Have a complex, extensive corporate supply chain system for the product they manufacture. In current scenario, Multinational Corporate responsible for not only for its direct activities but also for its suppliers such as in case of Rana Plaza Building disaster in Bangladesh.

\section{Economic Sustainability:}

The economic Dimension of sustainability concerns organizations' impact on the economic conditions of its stake holders and economic systems at local, national and global level. In the case of an organization, it means using available resources to their best advantage so the organization can continue to function over a number of years at a given level of Activity. We live in a Market based capitalistic society and it is important that corporations remain economically viable and vibrant in this system. This issue includes the following:

1. Long term Viability of business:

Our Reporting and financial systems are geared more towards the short term. Some argue that this leads to misleading decision making and an institutionalized failure to manage businesses for the longer term. 
2. Stability of Economic System:

The Global Financial Crisis showed how complex and interconnected our economic systems are. Further economic systems are integral part of human communities and breakdown have widespread consequences.

3. Transparency:

Transparency Refer to openness and authenticity about a corporation Operation and Strategy. Economic sustainability can be affected by many different factors. Transparency allows external stakeholders to appreciate the exposure of corporations to risk.

\section{REFERENCES}

1. Adams, C.A 2013, understanding Integrated Reporting: The Concise guide to Integrated Future of Corporate Reporting

2. Cohen. J, Holder-Webb, L. Wood. D \& Nath L-2012 "Discretionary Corporate Reporting of Non-Financial Performances metrics.

3. Dhaliwal. D, Radhakrishnan S. Tsang A \& George Y 2011 "Voluntary NonFinancial Disclosure and the cost of equity capital.

4. Dhaliwal. D, Radhakrishnan S. Tsang A \& young Y.G 2012: Non-Financial Disclosure and Analyst Forecast Accuracy: International evidence on corporate social responsibility disclosure. 